\title{
Eliter, populister og venstrebølgens endelikt i Latin-Amerika
}

Benedicte Bull og Francisco Sánchez

Publisert i Agora: Journal for metafysisk spekulasjon, 1-2 (2020), s. 88-110.

\section{Introduksjon}

Det er få andre felt der Latin-Amerika har vært så langt i forkant av utviklingen som når det gjelder populismen og studiet av den. Populismen som politisk fenomen har vært et sentralt kjennetegn ved utviklingen i regionen siden 1930-tallet, og har vært debattert i latinamerikansk samfunnsvitenskap siden 1950-tallet ${ }^{1}$. Latin-Amerika har også alltid vært en region preget av dyp sosial, økonomisk og politisk ulikhet, og stor avstand mellom eliter og andre grupper ${ }^{2}$. Anti-elitismen som kjennetegner den populistiske diskursen generelt, har derfor fått betydelig gehør i Latin-Amerika. Det gjaldt også under den såkalte venstrebølgen. Mellom årtusenskiftet og rundt 2015 var fleste av de større landene i Latin-Amerika styrt av selv-erklærte sentrumvenstre regjeringer. ${ }^{3}$ For å forklare framgangen for venstresiden i denne perioden har mange pekt på reaksjonen mot 1980 og 1990-tallets nyliberalisme som utdypet ulikheter uten å lykkes med å skape stabil økonomisk vekst. Samtidig ga gjeninnføring av demokrati rom for venstreorienterte sosiale bevegelser og politiske partier, som fant sammen i felles motstand mot nyliberalismen ${ }^{4}$. Ustabiliteten hadde også bidratt til dype institusjonelle kriser i flere land som venstresiden lovte en løsning på 5 .

Mens det i utgangspunktet var mye som skilte de nye venstreorienterte regimene, var de forent i kampen mot ulikhet og elitenes privilegier ${ }^{6}$. Noen av de venstreorienterte regimene hadde også klare trekk av populisme. Den uttalte anti-elitismen hos de venstreorienterte regjeringene

\footnotetext{
${ }^{1}$ Kirk A. Hawkins, og Cristobal Rovira Kaltwasser «The Ideational Approach to Populism», i Latin American Research Review, vol, 52, nr. 4, 2017, 513-528.

2 Javier Rodríguez, Weber. 2018. Alta desigualdad en América Latina: Desde Cuando y Porqué. Documento de Trabajo. Montevideo: Programa de Historia Económica y Social.

${ }^{3}$ De viktigste unntakene fra trenden var Mexico, Colombia og Peru. Heller ikke Panama og Guatemala har hatt venstreorienterte regjeringer, mens Honduras og Paraguay kun hadde det i svært korte perioder.

${ }^{4}$ Benedicte Bull «Social Movements and the 'Pink Tide' Governments in Latin America: Transformation, Inclusion and Rejection» i Kristian Stokke og Olle Törnquist, Democratization in the Global South: The Importance of Transformative Politics Houndmills. New York: Palgrave Macmillan 2013, 75-99.

${ }^{5}$ Francisco Sánchez og Simón Pachano, «Conclusions: Assessing the Left Turn in Latin America - 10 Years of the Correa Administration in Ecuador», i Francisco Sánchez og Simón Pachano (Eds.), Assessing the Left Turn in Ecuador. New York: Palgrave Macmillan 2020. 351-371.

${ }^{6}$ Maxwell Cameron og Eric Hershberg, Latin America's Left Turns: Politics, Policies, and Trajectories of Change. Boulder: Lynne Rienner Publisher 2011.

Benedicte Bull, "Combating Inequality: Is There a "Scandinavian Way" to Reduce Inequality in Latin America?», i Iberoamericana - Nordic Journal of Latin American and Caribbean Studies, vol. 48, nr. 1, 2019, 53-66.
} 
skapte betydelige motstand hos de tradisjonelle elitene, et tema som har vært gjenstand for en viss forskningsmessige oppmerksomhet ${ }^{7}$. Langt mindre har vært skrevet om i hvordan eliteendring kan være med på å forklare både fremveksten og utviklingen av venstresiden generelt, og de populistiske venstreregimene spesielt. I denne artikkelen argumenterer vi for at mens de populistiske venstreregimene til en viss grad var et resultat av fremveksten av det Torcuato di $\mathrm{Tella}^{8}$ kalte «inkongruente eliter», eller eliter som hadde akkumulert ulike ressurser, men i liten grad politisk makt, var skjebnen til de populistiske prosjektene avhengig av fremveksten av «alternative eliter», eller eliter knyttet til de nye regimene men med ressurser utover politiske kontakter. Implikasjonen er at selv om de venstreorienterte populistiske regimene kan kalles anti-establishment, eller i opposisjon mot tradisjonelle eliter, bidro de ikke til mindre elitistiske samfunn, men snarere til en endring av hvilke eliter som var dominerende.

Analysen baserer seg på en sammenlikning av fremveksten og utfallet av de to tydeligste eksemplene på populisme blant de venstreorienterte regimene: Hugo Chávez sitt styre i Venezuela og Rafael Correas i Ecuador. Populismen hos Chávez og Correa hadde mange likhetstrekk, blant annet en tydelig anti-elitistisk diskurs og politiske prosjekter som innebar en ny fordeling av statlige inntekter, i første rekke fra oljeutvinning. Deres regjeringsperioder endte imidlertid helt ulikt. «Chavismen» endte med en transisjon til et autoritært regime under Chávez' etterfølger Nicolás Maduro, men er fremdeles en politisk kraft i Venezuela. «Correismen» tok slutt som følge av at Rafael Correas utvalgte etterfølger, Lenin Moreno vant valget i 2017, og la om både stilen og politikken. Det har vært argumentert for at den naturlige endestasjonen for et populistisk styre er et autoritært regime ${ }^{9}$. Vi argumenterer for at det avhenger av hvorvidt alternative eliter ble etablert under de populistiske regimene. Mens det under Chavismen ble etablert en ny ikke bare politisk, men også økonomisk elite, skjedde dette i langt mindre grad i Correas Ecuador.

Vår definisjon av populisme baserer seg på De la Torre ${ }^{10}$, som bruker begrepet om et politisk fenomen som er et produkt av en bestemt måte å innlemme vanlige mennesker i det nasjonale samfunnet. Det er kjennetegnet av (i) en manikeisk diskurs som presenterer folkets kamp mot

\footnotetext{
${ }^{7}$ Liisa L. North, , Clark, Timothy D. (Eds), Dominant Elites in Latin America From Neo-Liberalism to the 'Pink Tide'. London: Palgrave 2018.

${ }^{8}$ Torcuato Di Tella, «Populismo y reforma en América Latina», i Desarrollo Económico, vol. 4, nr. 16, 1965, 130.

${ }^{9}$ Carlos De la Torre, «El populismo latinoamericano: entre la democratización y el autoritarismo», i Nueva Sociedad, nr. 247, 2013, 120-137.

${ }^{10}$ Carlos De la Torre, «Redentores populistas en el Neoliberalismo: nuevos y viejos populismos latinoamericanos», i Revista Española de Ciencia Política, nr. 4, 2001, 171-196.
} 
oligarkiet som en moralsk og etisk kamp mellom det gode og det onde; (ii) en leder som er sosialt konstruert som et symbol på frelsen; og (iii) en sosial bevegelse som knytter sammen fremvoksende eliter og marginaliserte grupper. Vår definisjon av eliter baserer seg på på Bull: Grupper som på grunn av deres vedvarende kontroll med økonomiske, politiske, sosiale, symbolske, makt- eller naturressurser er i en privilegert posisjon for å utøve formell eller uformell innflytelse i organisasjoner og institusjoner ${ }^{11}$.

Resten av artikkelen er strukturert som følger: I neste seksjon diskuterer vi hvordan «eliter er behandlet i ulike tilnærminger til populismeteori, med fokus på Latin-Amerika. I den påfølgende delen går vi inn på venstrebølgen og hvordan ulike forståelser av populisme er blitt brukt til å kritisere ulike venstreorienterte prosjekter og ledere. Deretter sammenlikner vi utviklingen av populismen og forholdet til ulike eliter under Hugo Chávez og Rafael Correa. Vi begynner med en diskusjon av hvordan deres fremvekst hadde utgangspunkt $\mathrm{i}$ «inkongruente eliter», og diskuterer så deres forhold til tradisjonelle eliter, og nye, alternative eliter som vokste frem som et resultat av deres politiske prosjekt.

\section{Latinamerikansk populisme, eliter og demokrati}

Forholdet mellom masser og eliter har vært sentralt i studiet av populisme i Latin-Amerika. De klassiske latinamerikanske populismestudiene så populismen som en form for maktrelasjon som oppstod mellom ledere og masser i en transisjon fra tradisjonelle til moderne samfunn. Med referanse til moderniseringsteori, argumenterte Gino Germani for at mens massene i Europa var blitt inkorporert gradvis i et liberalt-demokratisk politisk prosjekt, var dette umuliggjort i Latin-Amerika der man hadde et «uorganisk demokrati» med asymmetriske moderniseringsprosesser. Mens nylig urbaniserte masser ble inkorporert i arbeiderbevegelser og politiske partier i Europa, ble massene i Latin-Amerika mobilisert før kanaler for deltakelse var utviklet. Det ga grobunn for ulike politiske lederes manipulering av massene ${ }^{12}$. Populismen var i Germanis øyne i utgangspunktet anti-demokratisk, sentrert rundt en karismatisk leder og med grunnleggende irrasjonelle følgere.

Torcuato di Tella fulgte i samme teoretiske tradisjon, og så også populismen som et særtrekk ved underutviklede samfunn med lavt utdannede masser og manglende kanaler for inkorporering av dem i demokratiet. Til forskjell fra Germani mente di Tella at i en slik

\footnotetext{
${ }^{11}$ Benedicte Bull, «Elites, classes and environmental governance: conceptual and theoretical challenges», $\mathrm{i}$ Benedicte Bull og Mariel Aguilar-Støen, Environmental politics in Latin America: Elite dynamics, the left tide and sustainable development. Abingdon and New York: Routledge 2015, 15-30

${ }^{12}$ Gino Germani, Política y sociedad en una época de transición. Buenos Aires: Paidós 1968.
} 
kontekst, var sosial reform via demokratiske, pluralistiske kanaler blokkert. Den eneste kilden til slike reformer ville være fremveksten av en populistisk koalisjon med kraft til å mobilisere masser rundt et politisk prosjekt drevet av en ny elite ${ }^{13}$. Denne nye eliten ble omtalt som «inkongruent» fordi den hadde skaffet seg økonomiske og/eller andre ressurser, men så seg utestengt fra politisk makt av en «tradisjonell» elite. Utover en inkongruent elite, var kildene til den populistiske bevegelsen masser som var mobilisert som resultat av en «forventningsrevolusjon», og en ideologi og en følelsesmessig tilstand som legger til rette for kommunikasjon mellom ledere og følgere og som skaper en kollektiv entusiasme.

En del av de marxistisk inspirerte bidragene så også populismen som en elite-ledet strategi. De skilte imidlertid ikke mellom ulike (tradisjonelle og inkongruente/fremvoksende) eliter, men så populismen som de samlede herskende klassenes strategi for å nøytralisere en mulig autonom mobilisering. ${ }^{14}$ Etter hvert var det avhengighetsteoretiske perspektiver som dominerte innenfor marxistisk teori. Deres syn på populismen skilte seg radikalt fra Carmagnis når det gjaldt forholdet mellom populisme, eliter og demokrati. Disse pekte på at på tross av populistenes autoritære trekk, manipulering av massene og angrepene på den organiserte venstresida, så var populistenes nasjonalisme, statlige intervensjoner, og vektlegging av populær deltakelse og $\varnothing$ konomiske fordeling, nødvendige forutsetninger for demokratisering i Latin-Amerika ${ }^{15}$.

Selv om det normative og teoretiske utgangspunktet for disse tilnærmingene er ulikt, hadde de tidlige populismeteoriene til felles et fokus mobilisering av massene «fra oven» ved hjelp av konstruksjon og politisering av nye identiteter som står i motsetning til elitene. Massene deltar politisk gjennom sin direkte tilknytning til lederen, og uten politiske organisasjoner eller partier som mellomledd ${ }^{16}$. Denne tilnærmingen (av noen kalt organisasjonsmessig), er videreført av Weylands fortolkning av nyere populisme i Latin-Amerika, som han hevder kjennetegnes ved nettopp å være en politisk strategi der en personalistisk leder søker eller utøver regjeringsmakt gjennom direkte, ikke-institusjonell støtte fra en stor masse av stort sett uorganiserte følgere ${ }^{17}$.

En slik tilnærming har også hele tiden vært utfordret av de som så populismen som et $\varnothing$ konomisk fenomen. I utgangspunktet ble populismen knyttet til en import-substituerende

\footnotetext{
13 Di Tella, 1965, op.cit.

${ }^{14}$ Carmagini, 1980.

${ }^{15}$ Carlos María Vilas (red.), La democratización fundamental. El populismo en América Latina. México: Consejo Nacional para la Cultura y las Artes 1994.

${ }^{16}$ Anibal Viguera, ""Populismo” y “Neopopulismo” en América Latina», i Revista Méxicana de Sociología, vol. 55, nr. 33, 1993, 49-66.

${ }^{17}$ Kurt Weyland «Clarifying a Contested Concept: Populism in the Study of Latin American Politics», i Comparative Politics, vol. 34, nr. 1, 2001, 1-22.
} 
fordelingspolitikk fra 1930-tallet og fremover, men det ble etter hvert assosiert med en $\emptyset$ konomisk politikk med kortsiktige politiske målsetninger, som resulterer i en syklus av $\emptyset$ konomisk overstimulering, budsjettunderskudd, lånopptak og inflasjon ${ }^{18}$. Mens denne tilnærmingen først og fremst var populær i akademisk litteratur på 1990-tallet ${ }^{19}$, er den fortsatt dominerende i mye journalistikk og offentlig debatt i Latin-Amerika.

De siste årene har imidlertid en retorisk eller idemessig definisjon av populismen vunnet terreng også i Latin-Amerika. Den ser populisme som en politisk diskurs som deler folk inn i to motstridende leire: «folket» og «eliten», og peker ut lederen som folkets redning fra «eliten». Inn- og utgruppen defineres på ulike måter, men «folket» assosieres med ulike former for renhet, opprinnelighet og autensitet, mens «eliten» assosieres med korrupsjon, forfall, og svik. I Latin-Amerika har sviket vært forbundet med samarbeid eller unnfallenhet overfor USAs imperialisme. Populismens fokus på folkets absolutte suverenitet og politikken som uttrykk for folkeviljen gjør forholdet til liberale demokratiske institusjoner grunnleggende problematisk ${ }^{20}$. Særlig forholdet til ikke-flertallsdominerte institusjoner som rettsapparat og kontrollorganer er konfliktfylt siden populismens to-deling av folket bryter med det liberale demokratiets pluralisme ${ }^{21}$.

Den gryende konsensusen omkring en retorikk-fokusert definisjon har muliggjort sammenlikninger av populismen på tvers av tidsepoker og politisk identifikasjon på venstreeller høyresiden i Latin-Amerika. Man har kunnet sammenlikne de klassiske populistiske fenomenene og ledere som Getulio Vargas i Brasil, Lázaro Cárdenas i Mexico og Juan Domingo Perón i Argentina, med høyrepopulister som Carlos Menem, Fernando Collor de Mello og Alberto Fujimori og venstrepopulister som Hugo Chávez og Rafael Correa.

Samtidig kan en slik diskursiv definisjon bidra til å fjerne fokuset på mer langsiktige strukturelle betingelser og endringer med stor betydning for de langsiktige konsekvensene av populismen.

\footnotetext{
${ }^{18}$ Rudiger Dornbusch og Sebastian Edwards (eds.), The Macroeconomics of Populism in Latin America. Chicago: University of Chicago Press 1991.

Sebastian Edwards, Left Behind: Latin America and the False Promise of Populism. Chicago: University of Chicago Press 2010.

${ }^{19}$ Viguera, 1993, op. cit.

${ }^{20}$ Cas Mudde, «Populism: An Ideational Approach», i Cristobal Rovira Kaltwasser, Paul Taggart, Paulina Ochoa Espejo og Pierre Ostiguy, The Oxford Handbook of Populism. Oxford : Oxford University Press 2017.

${ }^{21}$ Saskia Pauline Ruth «Populism and the Erosion of Horizontal Accountability in Latin America», i Political Studies, vol. 66, nr. 2, 2018, 356-375.
} 
Den vanligste kritikken er at den fjerner fokuset fra de populistiske bevegelsene, og dermed på en mulig demokratiserende kraft i samfunnet ${ }^{22}$.

Motsvaret til denne tilnærmingen som ser populismen som styrt ovenfra og grunnleggende antidemokratisk er basert på Laclau og Mouffes tilnærming og ideen om et «populistisk tidspunkt»: en krisesituasjon der stadig flere sosiale krav forblir uoppfylt, og den hegemoniske politiske diskursen stilt spørsmålstegn ved, samtidig som demokratiet er avpolitisert. ${ }^{23}$ In en slik «postdemokratisk» situasjon er det populismen som muliggjør demokratisk deltakelse. Det skaper grobunn for et alternativt narrativ og et nytt anti-hegemonisk subjekt som representasjoner av folket. Mouffe aksepterer at «folket» er konstruert, men ser denne konstruksjonen som nødvendig. Skillet mellom en «virkelig» demokratisk populisme og en høyreorientert populisme trekkes på bakgrunn av hvorvidt man står i opposisjon til et dominerende nyliberalt prosjekt ${ }^{24}$. Under en slik forståelse ligger en marxistisk oppfatning av eliter som enhetlige og sammenfallende med de dominerende klasser. Eliter som mobiliserer massene i opposisjon mot nyliberalismen blir ansett for å delta i et grunnleggende demokratisk og progressivt prosjekt. Dette perspektivet har vært særlig innflytelsesrik i fortolkningen av nylige venstreorienterte populistiske regimer i Latin-Amerika, som blir forsvart ved å peke på hvordan de har omskap marginaliserte individer til politiske subjekter, og dermed utdypet snarere enn svekket demokratiet ${ }^{25}$.

En aksept av populismens anti-elitisme har gjort at få har studert relasjonene som utvikler seg mellom populistiske ledere og ulike eliter. I en $\phi$ konomisk forståelse er det den $\emptyset$ konomiske politikken, eller «policy» som er sentralt og ikke aktørene som utformer politikken. Implisitt ligger imidlertid en favorisering av en teknokratisk elite med dypere innsikt i økonomi og politikk, over de populistiske lederne og bevegelsene som er fokuserte på kortsiktig politisk gevinst. I en retorisk forståelse utgjør eliter i en eller annen form motpolen til folket i populistenes diskursive univers. Det å gjøre anti-elitismen til en generelt kjennetegn ved en

\footnotetext{
22 Paulina Ochoa Espejo, «Populism or Democracy? Reexamining the Role "the People” in Twenty-First Century Latin American Politics», i Tulia G. Faletti og Emilio Parrado, Latin America Since the Left Turn. Philadelfia: University of Pennsylvania Press 2017. 165-188.

Carlos De la Torre, "El populismo latinoamericano: entre la democratización y el autoritarismo», i Nueva Sociedad, nr. 247, 2013, 120-137.

${ }^{23}$ Ernesto Laclau, On Populist Reasoning. London: Verso 2005.

${ }^{24}$ Chantal Mouffe, For a Left Populism. London: Verso 2018.

${ }^{25}$ Carlos María Vilas, «Democracias conflictivas o el alegado resurgimiento populista en la política sudamericana», i Cuadernos Americanos: Nueva Epoca, vol.1, nr. 135, 2011, 31-56. Marc Saint-Upéry, El sueño de Bolívar. Buenos Aires: Ediciones Paidós 2008. Steven Ellner, «Pink-Tide Governments: Pragmatic and Populist Responses to Challenges from the Right», i Latin American Perspectives, vol. 46, nr. 1, 2019, 4-22.
} 
diskurs som i hovedsak har negative konnotasjoner betyr en implisitt avvisning av meningsinnholdet, og dermed også en avvisning populistenes egen påstand om at populismen er ikke-elitistisk. Den nye bølgen populisme i Europa blir også (som venstrebølgen i LatinAmerika) forstått som i bunn og grunn en reaksjon på et stadig mer elitisitisk og ekskluderende demokrati ${ }^{26}$. Men hovedfokuset er på konsekvensene av denne retorikken for polarisering og støtten til den populistiske lederen, ikke på hvordan populismen faktisk forholder seg til ulike eliter.

Forholdet mellom populistiske ledere og ulike eliter er imidlertid avgjørende for hvordan ulike populistiske prosjekt utvikler seg. Som de klassiske elitestudiene pekte på, vil eliter etableres i enhver organisasjon, og ingen statsledere kan over tid beholde makten uten støtte fra eliter, om de bygger sin elitestatus på sin posisjon i en statlig institusjon, militære, eller økonomiske og sosiale organisasjoner utenfor staten ${ }^{27}$. Utgangspunktet for Di Tella var eksistensen av misfornøyde eliter som opplevde en status-inkongruens, om det var aristokrater som hadde mistet formuen, nyrike handelsmenn, etniske minoriteter eller andre som på grunn av sosiale rigiditeter er ekskludert fra politisk innflytelse ${ }^{28}$. Slike inkongruente eliter skaper ustabilitet, også fordi de skaper nye forbilder for massene og en visjon om raske veier ut av fattigdom og misere. Deres ideologi står i kontrast til intellektuelle, som baserer seg på rasjonalistiske og humanitære ideer, som også kan inkludere marxisme.

Vi argumenterer her for at for å forstå utviklingen de populistiske prosjektene er det sentralt, ikke bare som argumentert for av Di Tella, å forstå de «inkongruente elitene» som populismen springer ut i fra, men også i hvilken grad de populistiske bevegelsene har bragt frem eliter som er alternative til de tradisjonelle elitene som har vært utgangspunktet for det populistiske prosjektets anti-elitistiske diskurs. Vår definisjon (gjengitt i innledningen) er i tråd med en «ressursbasert forståelse» der eliter kan springe ut fra kontroll med ulike ressurser, ikke bare kapital og politiske institusjoner, men også blant annet voldsapparat, symboler, og kunnskap. Disse kan være overlappende, og det er kombinasjonen av kontroll over ulike ressurser over en viss tid som avgjør hvorvidt grupper etableres som eliter ${ }^{29}$.

\footnotetext{
${ }^{26}$ Malte Frøslee Ibsen «The Populist Conjuncture: legitimation Crisis in the Age of Globalizaed Capitalism», i Political Studies, 2018, 1-17.

${ }^{27}$ Robert Mitchels, R. Political Parties. New York: Free Press 1962. Gaetano Mosca, The Ruling Class. New York: McGraw Hill 1939.

${ }^{28}$ Di Tella, 1965, op.cit.

${ }^{29}$ Benedicte Bull, «Elites, classes and environmental governance: conceptual and theoretical challenges», i Benedicte Bull og Mariel Aguilar-Støen, Environmental politics in Latin America: Elite dynamics, the left tide and sustainable development. Abingdon and New York: Routledge 2015, 15-30.
} 
Noen av de populistiske lederne har kommet til makten med en eksplisitt plan om å styrke alternative eliter, men dette er alltid (som vist under i tilfellet Chávez) pakket inn i retoriske grep som gjør disse elitene til en del av folket. Vår hypotese er at i den grad det lykkes å etablere en alternativ elite vil dette gjøre de populistiske bevegelsene mer varige, men også trusselen mot demokratiet mer langsiktig.

\section{Venstrebølgen, elitene og den nye populismen}

Helt i utgangspunktet ble merkelappen «populistiske» hengt på de mer radikale av de venstreorienterte regimene, på en måte som skulle skille den «gode, moderate» venstresida fra den «dårlige» radikale. ${ }^{30}$ Også senere ble karakteristikken «populist» flittig brukt. Den blir brukt både til å forklare hvorfor venstreregjeringene etterlot seg $\varnothing$ konomiske problemer og sviktende tillit til demokratiske institusjoner, og hvorfor de til slutt enten ble byttet ut eller forvitret til autoritære regimer. For noen bestod «populismen» i en utgiftsbonanza: låneopptak, inflasjon og økonomisk kollaps. For andre bidro «populismens» personfiksering og sterke lederskap til polarisering, sosial uro og legitimitetskrise ${ }^{31}$. Den $\varnothing$ konomiske forståelsen av populisme lå bak mye av kritikken. Flere av de nye venstreorienterte regimene baserte sin politikk på en utvidet rolle for staten, gjennom $\varnothing \mathrm{kt}$ statlig eierskap i næringslivet, og $\varnothing \mathrm{kte}$ statlige overføringer og sosiale tjenester. ${ }^{32}$ Det gjaldt både Luis Inacio Lula da Silva (20032010) og hans partifelle og etterfølger Dilma Rouseff (2011-2016) fra det brasilianske arbeiderpartiet (PT); Boliva under Evo Morales fra Bevegelsen mot Sosialisme (MAS); Ecuador under Rafael Correa (2007-2017); Argentina under peronistlederne Nestor Kirschner (2003-2007) og Cristina Fernández (2007-2015); og ikke minst, Hugo Chávez sitt styre i Venezuela (1999-2013). På den annen side fikk man under sosialistpartiets Ricardo Lagos (2000-2006) og Michelle Bachelet (2006-2010 og 2014-2018) i Chile og under Pepe Mujica (2010-2015) og Tabaré Vázquez (2005-2010 og 2015-) i Uruguay en utvidelse av sosiale programmer uten noen sterk styrkning av statens rolle i økonomien. Også ikke-venstreorienterte regjeringen $\varnothing$ kte de sosiale utgiftene i dette tidsrommet, og mens de fleste av de typisk råvareavhengige landene i Sør-Amerika opplevde økonomiske problemer etter råvareprisfallet

\footnotetext{
${ }^{30}$ Jorge Castañeda, Latin America's Left Turn: There is More Than One Pink Tide, Foreign Affairs, May-June 2006.

${ }^{31}$ Kurt Weyland, "The threat from the populist left", Journal of Democracy, Volume 24, Number 3, July 2013, pp. 18-32.

${ }^{32}$ Benedicte Bull, "Latin America's decade of growth: progress and challenges for sustainable development», $\mathrm{i}$ A. Hansen og U. Wethal, Emerging Economies and Challenges to Sustainability: Theories, strategies, local realities. London og New York: Palgrave 2015. 123-133.
} 
rundt 2014, var det bare i Venezuela, Argentina og Ecuador at en «populistisk» utgiftsøkning kan sies å ha vært hovedårsak til alvorlig økonomisk ubalanse, og bare Venezuela og Argentina som opplevde høy inflasjon som følge. ${ }^{33}$

Heller ikke en mer institusjonell eller organisasjonsmessig definisjon av populisme treffer de fleste venstreorienterte regimene. Ideen om at «massene» som følger den populistiske lederen er så uorganisert som for eksempel Weyland vil ha det til, er blitt kritisert på generelt grunnlag ${ }^{34}$. Ser man mer spesifikt på de ulike venstreorienterte regimene, er det helt åpenbart at verken Lulas Brasil eller Evo Morales' Bolivia passer til denne beskrivelsen. Begge er tidligere fagforeningsledere som gjennom en årrekke systematisk har bygget opp og jobbet igjennom sosiale bevegelser og politiske partier, og søkt politisk makt gjennom demokratiske kanaler. Selv om de er svært profilerte ledere av henholdsvis PT og MAS, er partiene på ingen måte kun et valgkampmaskineri bygget opp rundt dem. Det samme kan sies om Partido Justicialista (peronistpartiet) som fostret Nestor Kirchner og Cristina Fernández de Kirchner ${ }^{35}$.

De som tydeligst skiller seg ut som populistiske i tråd med vår definisjon er Hugo Chávez og Rafael Correa. Det var egentlig bare disse to som konsekvent baserte sin strategi på å konstruere et fiendskap mellom massene og eliten. Hawkins ${ }^{36}$ gir også Evo Morales sin retorikk høy «populistscore», men han skilte seg fra Correa og Chávez ved sin langt mer pragmatiske (og til tider doble) diskurs, overfor tradisjonelle eliter ${ }^{37}$, og mindre vekt på å konstruere seg selv som frelseren. Det samme kan sies om Lula, mens hans etterfølger og partifelle Dilma Rouseff snarere en klassisk utviklingsoptimist ${ }^{38}$, og mer teknokrat enn populist. Når vi i det følgende ser på populistregimenes utvikling og forhold til eliter, fokuserer vi på disse to: Hugo Chávez i Venezuela og Rafael Correa i Ecuador.

\section{Populisme, eliter og kollaps i Venezuela og Ecuador}

\footnotetext{
${ }^{33}$ En viktig årsak til at ikke Ecuador ble offer for det samme, var at økonomien ble dollarisert i 2000 som følge av tidligere erfaringer med hyperinnflasjon.

${ }^{34}$ Carlos De la Torre «The Resurgence of Radical Populsm in Latin America», i Costtellations, vol. 14, nr. 3, 2007, 385-397.

${ }^{35}$ Benedicte Bull «Comparing Critical Junctures: The Democratic Inclusion of Social Movements in Norway and Latin America», i Forum for Development Studies, vol. 34, nr. 1, 2007, 63-89.

${ }^{36}$ Kirk A. Hawkins «Is Chávez Populist?: Measuring Populist Discourse in Comparative Perspective", i Comparative Political Studies, vol. 42, nr. 8, 2009, 1040-1067

${ }^{37}$ Linda Farthing «An Opportunity Squandered? Elites, Social Movements, and the Government of Evo Morales», i Latin American Perspectives, vol. 46, nr. 1, 2019, 212-229. Jonas Wolff, "Las élites políticas y económicas en Bolivia y Ecuador: convivir con gobiernos posneoliberales», i Adriano Codato og Fran. Espinoza (Eds.), Elites en las Américas). Curitiba: Editora UFPR 2018. 73-115.

${ }^{38}$ Luiz. Carlos Bresser Pereira, «State society cycles and political pacts in a national dependent society: Brazil», i Latin American Research Review, vol. 50, nr. 2, 205, 3-22.
} 
Venezuelansk og Ecuadoriansk politikk sentrerte begge i over et tiår rundt én enkelt personlighet: henholdsvis Hugo Chávez (ved makten fra 1999-2013) og Rafael Correa (20072017). Igjennom den perioden ble politikken i begge land dypt polarisert og institusjoner som begrenset statsmakten svekket, mens statens plass i økonomi og samfunnsliv ble styrket.

Slutten på deres regjeringstid ble imidlertid svært forskjellig. Hugo Chávez døde i 2013, og hans utpekte etterfølger Nicolás Maduro vant valget i etterkant. Han har sittet ved makten siden. Venezuela har i løpet av Maduros regjeringstid gått fra å være et konstitusjonelt demokrati, begrenset av en populistisk leders gradvise underminering av liberale institusjoner, til å være et autoritært, ny-patrimonialt regime. ${ }^{39}$ Bevegelsen som Chávez bygget opp - «Chavismen» lever videre selv om den har gjennomgått store endringer.

I Ecuador var Correa konstitusjonelt forhindret fra å stille til valget i 2017. Han støttet derfor sin tidligere allierte Lenin Morenos kandidatur. Moreno distanserte seg raskt fra Correa og beskyldte ham for korrupsjon og for å ha ødelagt økonomien. Korrupsjonsanklager endte med at Correa og flere nære medarbeidere ble fengslet eller rømte landet. Moreno forbedret forholdet til mediene og opposisjonene som hadde vært svært anstrengt under Correa, og forhandlet frem en pakt med høyresiden. For å styrke sin legitimitet innkalte han til en folkeavstemning for å forby gjenvalg, og å styrke rettsvernet mot korrupsjon. I løpet av kort tid var Correas parti redusert til et irrelevant miniparti, og den mektigste presidenten i Ecuadors nyere historie var i eksil i Belgia uten mulighet til å komme tilbake til hjemlandet ${ }^{40}$. Hvorfor endte det så ulikt?

\section{Populistenes og de inkongruente elitene}

Både Chávez og Correa kom til makten midt en dyp politisk og økonomisk krise. De var begge politiske outsidere - personer uten politisk erfaring som operererte i et demokratisk terreng, men som konstant angrep demokratiets hovedaktører og institusjoner ${ }^{41}$. Correa var så ukjent for de fleste, at en av landets mest kjente urfolksledere Cotacachi Auki Tituaña kalte ham "Huairapamushca”, «vindens sønn» på quichua, eller en som mangler røtter og ikke tilhører noe fellesskap. Ingen av dem hadde heller Morales' eller Lulas erfaring med organisasjonsbygging og politiske forhandlinger.

\footnotetext{
39 Jennifer McCoy og Dimitris Pantoulous, Venezuela: an unstable equilibrium Venezuela: un equilibrio in estable Revista de Ciencia Política, 2019, 39(2):391-408; Margarita López Maya, Populism, 21st-century socialism and corruption in Venezuela, 2019, Volume: 149 issue: 1, page(s): 67-83 Article first published online: December 14, 2018; Issue published: December 1, 2018

${ }^{40}$ Felipe Burbano de Lara «Parricidas, leales y traidores. La dramática transición ecuatoriana hacia el poscorreísmo», i Ecuador Debate, nr. 102, 2017, 9-26.

${ }^{41}$ Rene Antonio Mayorga, Antipolítica y neopopulismo. La Paz: Cebem 1995.
} 
I Venezuela hadde elite-kompromisset som ble inngått ved overgangen til demokrati i 1958 (kalt Punto Fijo avtalen), resultert i demokratisk stabilitet, men eksklusiv maktfordeling mellom to partier (COPEI og Acción Democrática (AD)). Disse partiene delte ikke bare den politiske makten men også tilgangen til oljeinntekter, som smurte en betydelig økonomisk vekst og utviklingen av et velferdssystem på 1960-70-tallet. Med oljeprisøkning, og en voldsom økning i statlige utgifter og korrupsjon under president Carlos Andrés Pérez' første regjering (19741979), ble grunnlaget lagt for kollapsen som kom på 1980-tallet gjennom høye låneopptak, produksjons- og produktivitetsfall. Krisen som fulgte etter oljeprisfallet og renteøkning på tidlig 1980-tall, er ofte fortolket som et resultat av det foregående tiårets oljeprisgenererte overopphetingen og «hollandsk syke» ${ }^{42}$. Etter den brutale nedslaktningen av deltakere i en demonstrasjon mot fattigdom og strukturtilpasning i 1989 (kalt Caracazo) i begynnelensen av Pérez' andre regjering (1989-1993), forsøkte den unge oberstløytnanten i hæren, Hugo Chávez, seg på et kupp i 1992. Han kom fra beskjedne kår på landsbygda. Fra fengselet utviklet han sin politiske plattform og la videre planer for maktovertakelse.

Da Chávez stilte til valg i 1998 hadde både Copei og AD kollapset, og ingen av dem klarte før i siste liten å enes om en motkandidat. Chávez vant klart med støtte av en koalisjon bestående av 13 ulike venstreorienterte bevegelser og partier, inkludert hans eget Movimiento Quinta República (MVR) ${ }^{43}$ Han hadde også klar støtte blant inkongruente eliter både blant militære og næringslivet ${ }^{44}$. MVR var bevisst etablert som en løst sammensatt bevegelse for å sikre Chávez sitt kandidatur, snarere enn et politisk parti. Det reflekterte Chávez sin generelle forakt for politiske partier. ${ }^{45}$ Den store valg-koalisjonen gikk også snart i oppløsning.

Correas valgseier i Ecuador kom også etter en $\varnothing$ konomisk krise, inflasjon og fattigdoms $\varnothing$ kning på 1980 og 90-tallet. Voldsomme demonstrasjoner tvang i 1997 president Abdala Bucarán til å gå av. President Jamil Mahuad led samme skjebne etter finanskrisen i 2000, som førte til dollariseringen av økonomien samme år. Lucio Gutierrez (militæroffiseren som kastet Mahuad)

\footnotetext{
42 Terry Lynn Karl, The Paradox of Plenty: Oil Booms and Petro-States. Oakland: University of California Press 1997.

Jonathan Di John «Economic Liberalization, Political Instability, and State Capacity in Venezuela», i International Political Science Review / Revue internationale de science politique, vol, 26, nr, 1, 2005, 107-124.

${ }^{43}$ De viktigste av de andre var Movimiento al Socialismo (MAS) Causa Radical (Causa R), Partido Comunista, Polo Patriótico, Patria Para Todos

${ }^{44}$ Leslie C. Gates, "Interest groups in Venezuela: lessons from the failure of a 'Model Democracy' and the rise of a Bolivarian democracy», i Journal of Public Affairs, vol. 14, nr, 3-4, 2014, 240-253.

William Avilés, «Policy Coalitions, Economic Reform and Military Power in Ecuador and Venezuela», i Third World Quarterly, vol. 30, nr. 8, 2009, 1549-1564.

${ }^{45}$ Gabriel Hetland, From System Collapse to Chavista Hegemony: The Party Question in Bolivarian Venezuela, Volume: 44 issue: 1, 2017, 17-36.
} 
ble den tredje presidenten som ble avsatt etter uroligheter i 2005. Etter det ble folks forakt for politikere generalisert, og Ecuador ble stadig oftere omtalt som «ustyrbart» (ingobernable) ${ }^{46}$.

I den konteksten ble Rafael Correa fremmet som den perfekte kandidaten av den løst sammensatte ad-hoc bevegelsen Det Høyverdige og Suverene Moderlandet (Patria Altiva y Soberana (PAIS)), etablert bare måneder før valget i 2006. Correa kom fra en Ecuadors nest største by- og næringslivssentrum, Guayaquil. Guayaquil-eliten har alltid konkurrert med eliten fra høylandet og hovedstaden Quito, men også vært omskiftelig. Internasjonal handel og finans har vært Guayaquil-elitens viktigste ressursgrunnlag, men nye grupper har kommet til, blant annet en betydelig elite av libanesisk opphav som ga sin støtte til Bucarán og Mahuad av samme etniske opprinnelse.

Correa kom fra en familie med store ambisjoner men begrensede ressurser. Situasjonen var så vanskelig at faren til Correa prøvde seg på narkotikasmugling, og ble fengslet i USA i flere år da han var liten. ${ }^{47}$ På tross av det fikk han hele sin utdanning ved katolske, private eliteskoler. Mange av hans senere nærmeste politiske medarbeidere er tidligere klassekamerater var fra disse privatskolene ${ }^{48}$. Senere tok han en doktorgrad i økonomi fra University of Illinois, og ble lærer på det private eliteuniversitetet Universidad San Francisco.

Correas manglende tidligere politiske erfaring, og dermed også manglende negative omdømme, ble sett på som en viktig fordel. ${ }^{49}$ Hans første politiske erfaring var som rådgiver for finansministeren under Gutierrez. Da Gutierrrez ble kastet, og Alfredo Palacios fra Correas hjemby Guayaquil tok over, ble Correa finansminister i fem måneder (fra April til August 2005). I løpet av disse fem månedene ble han kjent for sin polemiske stil og harde utfall mot de internasjonale finansinstitusjonene.

Allerede under den første valgkampen ble en del kjennetegn ved hans lederstil tydelige. Med klare religiøse overtoner fremstilte han de fleste saker som en kamp mellom det gode og det onde. ${ }^{50}$ Fokuset var på å fremstille Correa som mannen som kunne redde Ecuador både fra

\footnotetext{
${ }^{46}$ Francisco Sánchez, «Antecedentes recientes de la situación política ecuatoriana», i lberoamericana. nr. 8, 2002, 187-196.

${ }^{47}$ https://www.perfil.com/noticias/internacional/correa-admitio-que-su-papa-estuvo-preso-por-droga20070414-0031.phtml

${ }^{48}$ Mónica Almeida og Ana Karina López, El séptimo Rafael. Biografía no autorizada de Rafael Correa Delgado, expresidente del Ecuador. Quito: Aperimus 2019.

${ }^{49}$ Universo de Guayaquil 19. Juli 2006.

${ }^{50}$ Catherine Conaghan, "Surveil and Sanction: The Return of the State and Societal Regulation in Ecuador», i European Review of Latin American and Caribbean Studies / Revista Europea de Estudios Latinoamericanos y del Caribe, nr. 98, 2015, 7-27.
} 
interne fiender og den globale kapitalismen. Valgkampen ble ført under mottoet og ordspillet «Dale Correa» som både kan bety «gi dem inn, Correa» og «gi dem en omgang med beltet» (Correa betyr belte). Samtidig videreførte Correa lange tradisjoner for «den sterke manns styre» (caudillismo). Hans regjering er blitt definert som «plebisittisk hyperpresidensialisme» ${ }^{51}$ karakterisert ved fokuset på ham som lederperson, legitimert gjennom hyppige valg og folkeavstemninger. Han var i konstant politisk kampanjemodus, og brukte en rekke teknikker fra politisk marketing for å mobilisere massene ${ }^{52}$.

Etter den første valgseieren møtte Chávez raskt sterk motstand fra de tradisjonelle elitene i Venezuela. På tross av å ha mistet politisk innflytelse, hadde de fortsatt betydelig økonomisk makt, ikke minst gjennom kontroll med oljeselskapet PDVSA. Chávez sin første store seier var nedsettelsen av den grunnlovgivende forsamlingen, og vedtak av en konstitusjon for den nyomdøpte «Bolivarianske Republikken Venezuela». Den nye konstitusjonen styrket presidentembetet ved blant annet å fjerne senatet og gi mulighet for fullmaktslovgivning ${ }^{53}$. Ved hjelp av fullmaktsloven fra 2001 ble det vedtatt omfattende lovendringer ved dekret, noe som generte stor motstand blant den tidligere eliten. Motstanden toppet seg etter Chávez' sitt fors $\varnothing \mathrm{k}$ på å sike kontroll over oljeselskapet PDVSA som lenge hadde fungert som en stat i staten og hvis både ledelse og fagforeninger var knyttet til de tradisjonelle partiene. Striden endte med det mislykkede kuppfors $\varnothing$ ket ledet av presidenten i næringslivsorganisasjonen Fedecamaras i April 2002.

Chávez' viktigste støttespillere var på den ene siden «folket» og på den andre siden de militære. Folket ble konstruert som et enhetlig og moralsk høyverdig subjekt, som stod i en klar motsetning til «oligarkiet» og «imperiet i nord» - USA. Chávez sin diskurs, blant annet fremført i hans lange TV-taler, er grundig studert, ${ }^{54}$ og av Hawkins karakterisert som den mest typisk populistiske diskursen fra noen leder, ikke bare i Latin-Amerika, men i en global kontekst ${ }^{55}$

\footnotetext{
${ }^{51}$ Catherine Conaghan og Carlos de la Torre, «The Permanent Campaign of Rafael Correa: Making Ecuador's Plebicitary Presidency», The International Journal of Press/Politics, vol. 13, nr. 3, 2008, 267-284.

${ }^{52}$ Carlos De la Torre og Catherine Conaghan, «The Hybrid Campaign: Tradition and Modernity in Ecuador's 2006 Presidential Election» i The International Journal of Press/Politics, vol.14, nr. 3, 2009, 335-352.

53 Javier Corrales «The Authoritarian Resurgence: Autocratic Legalism in Venezuela», i Journal of Democracy, $\mathrm{nr}, 2,2015,37-51$.

${ }^{54}$ Se for eksempel Nelly Arenas og Luis Gómez Calcaño . «El imaginario redentor: de la "Revolución de Octubre" a la Quinta República», i Anuario ININCO / Investigaciones de la Comunicación, vol. 29, nr.1, 2017, 2978.

${ }^{55}$ Kirk A. Hawkins «ls Chávez Populist?: Measuring Populist Discourse in Comparative Perspective”, i Comparative Political Studies, vol. 42, nr. 8, 2009, 1040-1067.
} 
Den hadde dype religiøse overtoner, og var sentrert rundt konstruksjonen av ham selv som frelseren ${ }^{56}$, som illustrert i det følgende fra valgkampen i 1998:

Foran dere, Venezuelanere, er det to mulige veier, ikke mer. Og som Bibelen sier - og Guds ord er alltid kloke - kan man ikke samtidig være med Gud og med djevelen; man er enten med Gud eller djevelen. Hver av dere velger deres vei. De som vil at Venezuela skal fortsette å synke ned i korrupsjon, tilbakeliggenhet, misere, og en barbarisk nyliberalisme, som skaper arbeidsledighet, sult og fattigdom, de kan fortsette å stemme på de korrupte, som ikke er annet enn herr Salas Römer ${ }^{57}$... De som ønsker at Venezuela kommer seg ut av denne mørke labyrinten .... de som vil at Venezuela tar skrittet inn i fremtiden ... alle som vil frelse Venezuela, følg meg .... Som Jesus sa en dag, få en slutt på at de døde begraver sine $\mathrm{d} \varnothing \mathrm{de}$. Kom med oss til livet, til fremtiden, til håpet, til gjenoppstandelsen av et folk, et nytt fedreland (Hugo Chávez, tale ved slutten på valgkampen, 2-12-1998).

Den andre viktige pilaren var militæret. Chávez hadde hele sin utdanning og yrkeskarriere i det militæret og han vektla jevnlig at først og fremst var han en soldat i folkets tjeneste. Den Bolivarianske revolusjonen var i utgangspunktet en «sivil-militær prosess».. Noe av det første Chávez gjorde som president var å kalle ut de militære styrkene under den såkalte «Plan Bolivar» i 2000 for å bygge infrastruktur og legge til rette for de mange ulike sosiale prosjektene. Etter kuppfors $\varnothing$ ket i 2002, ble det foretatt en utrenskning av de militære som hadde deltatt, og planene ble lagt for å styrke den militære siden av revolusjonen ${ }^{58}$.

Correa manglet Chávez sin støtte hos institusjonsbaserte inkongruente eliter. Hans allianse var langt løsere sammensatt av mindre grupper blant de økonomiske elitene fra Guayuaquil, og politisk progressive eliter på venstresida fra de høyre utdannede gruppene basert rundt hovedstaden Quito.

\section{Populistene og de tradisjonelle elitene}

Sammen med en sterk populistisk diskurs som beskrev «folket», som autentiske, patriotiske nasjonalister, sikret Chávez og Correa støtte fra folk flest gjennom store sosiale programmer. I Venezuela ble såkalte sosiale «misjoner» rullet ut for å få til rask reduksjon av fattigdom,

\footnotetext{
56 José Pedro Zúquete, «The Missionary Politics of Hugo Chávez», i Latin American Politics and Society, vol. 50, nr. 1, 2008, 91-121.

${ }^{57}$ Hans motkandidat i valget.

${ }^{58}$ Luis Esteban González Manrique «Las Fuerzas Armadas como partido político: la nueva "geometría del poder" chavista», i Análisis del Real Instituto Elcano ARI, nr. 117, 2007, 1-6.
} 
alfabetisering, forbedret helsevesen og rask utbygging av sosiale boligprosjekter. De var godt hjulpet av kontrollen som var sikret over oljeselskapet PDVSA og raskt økende oljepriser fra 2003. ${ }^{59}$ Etter kuppforsøket mot Chávez i 2002, økte motstanden mot Chávez blant opposisjonspartier og næringsliv, mens Chávez verbale, juridiske og økonomiske angrep på enkeltmedlemmer av den tradisjonelle eliten ble stadig hyppigere. ${ }^{60}$ Det ga seg utslag i alt fra utskjelling på TV til en bølge av ekspropriering, politisk styrt implementering av pris og valutakontroller, og politisk styrt utdeling av lisenser og kontrakter. ${ }^{61}$

Etter hvert ble de verbale angrepene stadig mer rettet mot USA, og den tradisjonelle eliten ble i større grad forsøkt konstruert som anti-nasjonalistiske løpegutter for imperialisten i nord. Det følgende sitatet fra valgkampen i 2006 illustrerer Chávez sin diskurs:

La ingen glemme at vi står overfor djevelen selv. Søndag 3. Desember skal vi konfrontere den imperialistiske regjeringen i Nord Amerikas Forente Stater ved valgurnene. Det er vår virkelige motstander, ikke disse «har vært» her, disse imperialistenes lakeier .... Lenge leve Kristus, den første revolusjonære i vår tid! Folkets martyr, Kristus Frelseren, i dag er hans dag, Kristus Kongens dag ... Dere, folket, er kjempen som våknet. Jeg, deres ydmyke soldat, vil bare gjøre som dere sier. Jeg står til deres tjeneste for å fortsette å bane veien til det store Fedrelandet... For dere skal ikke egentlig gjenvelge Chávez. Dere skal gjenvelge dere selv, folket skal gjenvelge folket. Chávez er bare et instrument for folket.

Som Chávez fors økte Correa konsekvent å konstruere «folket» som et enhetlig subjekt, og som opprinnelsen for hans mandat. Hans фkonomiske og sosiale prosjekt var basert på to hovedpillarer: utbygging av infrastruktur, og sosiale og fordelingsprogram basert på direkte kontantoverføringer til fattige, og forbedring av helse og utdanningstjenester. Også Ecuador er en oljeproduserende stat om ikke i samme omfang som Venezuela, og også Correa var godt hjulpet av $\varnothing$ kte oljepriser. Inntektene ble blant annet brukt til å styrke statens evne til å implementere sosialpolitikk og store prosjekter ${ }^{62}$.

I valgkampen i 2013 sa Correa seg godt fornøyd med resultatet:

\footnotetext{
${ }^{59}$ Steven Ellner, «Class Strategies in Chavista Venezuela: Pragmatic and Populist Policies in a Broader Context», i Latin American Perspectives, vol. 46, nr. 1, 2019, 167-189.

${ }^{60}$ Ellner, 2019

${ }^{61}$ Benedicte Bull og Antulio Rosales, "Into the Shadows: Sanctions, Rentierism and the Informalization of the Venezuelan Economy", European Review of Latin American and Caribbean Studies, 2020, forthcoming.

62 Sánchez og Pachano (Eds.), Assessing the Left Turn in Ecuador. New York: Palgrave Macmillan 2020.
} 
Vi har gjenvunnet verdigheten, troen, tilliten til oss selv: Men vet dere hva som er den største premien for denne endringen? For meg er dere det viktigste, disse ansiktene av håp, disse blikkene fylt med optimisme, å ha gjenvunnet selvtilliten. Vi har latt dem stjele alt bortsett fra håpet, men som en fugl Fønix, har det Ecuatorianske folket og Fedrelandet steget opp av nyliberalismens aske.

Han møtte imidlertid raskt på en utfordring når det gjaldt å konstruere folket som enhetlig: at en stor del av Ecuadors befolkning er av urfolksopprinnelse. Ecuador har lenge hatt det som regnes for Latin-Amerikas sterkeste urfolksbevegelse: Konføderasjonen av Urfolk og Nasjonaliteter i Ecuador (CONAIE). Den var en drivkraft bak presidentavsettelsene på sent 1990-tall og tidlig 2000-tall, og tok aktiv del i Grunnlovsforsamlingen som ble nedsatt i 2007. Både den nye grunnloven og regjeringens diskurs vektla i etterkant tankegods med opprinnelse hos urfolk som en viktig plattform for det nye Ecuador ${ }^{63}$. Dette tankegodset ble oppsummert i begrepet Buen Vivir (Sumak Kawsay), som peker på et godt liv i harmoni med naturen. Men CONAIE kom fort på kant både med Correa’s autoritære lederstil og hans utviklingspolitikk. Den var langt mer i tråd med en tradisjonell latinamerikanske «desarrollismo», enn «buen vivir». Hans hovedfokus var på fordeling og fattigdomsreduksjon gjennom modernisering og $\emptyset$ konomisk vekst, med den forskjellen fra «desarrollistene» at veien til modernisering først og fremst gikk via naturressursutvinning. På tross av tidlige initiativer for naturbevaring, $\varnothing \mathrm{kte}$ Correa utbyggingen og utvinningen av olje, og begynte storstilt gruvedrift ${ }^{64}$. Det gikk på tvers av urfolksiniteresser og CONAIE ble raskt blant Correas hovedopponenter, noe som vanskeliggjorde konstruksjonen av «folket» som enhetlig.

Forsøk på dialog med urfolksbevegelsen brøt snart sammen etter at Presidenten gjorde det klart at en gruppe som bare fikk $2 \%$ av stemmene ved valget (med referanse til stemmene til kandidaten til urfolkspartiet Pachakutik) ikke kunne påtvinge sin agenda. Etter det trakk regjeringen tilbake støtten til CONAIE, forfulgte lederne ved å beskylde dem for terrorisme, undertrykte demonstrasjoner i strid med konstitusjonen, og fors $\varnothing \mathrm{kte}$ å frata dem hovedsetet $\mathrm{i}$ Quito. Sammen med NGOer og andre miljøaktivister ble de stadig kalt «den barnslige venstresida» og umodne marionetter for utenlandske interesser ${ }^{65}$. En andre store sosiale

\footnotetext{
63 Jorge Resina De la Fuente, La transformación del Estado y el rol del movimiento indígena durante el Gobierno de Correa. Quito: Editorial AbyaYala, 2015.

${ }^{64}$ Pablo Andrade, «El Gobierno de la Naturaleza: La gobernanza ambiental posneoliberal en Ecuador y Bolivia», i Fabio De Castro, Barbara. Hogenboom og Michiel Baud, Gobernanza Ambiental en América Latina. Buenos Aires: CLACSO 2015, 135-169.

${ }^{65}$ Francisco Sánchez (2012), Quien tiene boca, se equicoca, pero el que tiene seso, no dice eso. Valencia: Acracia Editorial 2012.
} 
bevegelsen, Den Nasjonale Lærerunionen (UNE), fikk samme behandling, med økonomisk strupetak og forfølgelse av lederne.

Correa møtte imidlertid ikke samme motstand fra den tradisjonelle eliten som Hugo Chávez. Elitene i Ecuador var enda sterkere svekket enn i Venezuela da Rafael Correa kom til makten. Partisystemet bestod av en rekke småpartier, hvorav ingen var verken dominerende eller godt organisert. Fra kongressen hadde de imidlertid den lovgivende makten, og makt til å styre

Legitimitetskrisen som partisystemet befant seg i, ble kløktig utnyttet av Correa fra første $\emptyset$ yeblikk. Han fremstilte seg som mannen som hadde gjort slutt på det han kalte «partikratiet».

Det ecuatorianske folk sa nok er nok til partikratiets regjeringer, de sa stop til de kriminelle bankene, de sa stop til løgnhalsene som aldri oppfylte valgløftense sine. De sa stop til mediebusinessen og de som gang etter gang utnyttet deres godhjet og tålmodighet (Rafael Correa, valgkamptale 2013).

Gjennom den første valgkampen argumenterte han for å nedsette en Grunnlovgivende Forsamling, og å stenge hele kongressen som var partienes kilde til makt. Derfor presenterte hans parti PAIS bare ham som presidentkandidat, og ikke en eneste kandidat til kongressen. Da han først var kommet til makten avsatte han Valgdomstolen (Tribunal Supremo Electoral). I en prosess som beveget seg i den legale gråsonen avsatte han 57 av 100 kongressmedlemmer. Etter det var det eneste gjenværende sentrum for opposisjon mot Correa ironisk nok Guayaquil, Correas hjemby. Det er landets nest største by og økonomiske sentrum og var styrt av et høyreorientert parti.

Privat sektor i Ecuador var sterkt svekket etter den økonomiske krisa, og særlig en alvorlig bank- og finanskrise i 1997-200. Verken arbeidsgiverorganisasjoner eller handelskamre var politiske aktører å regne med. Fokuset for Correas konfrontasjoner ble derfor bankene og mediene, og som samlebegrep for disse og andre eliter brukte han «parykk-gjengen» («peluccones») med referanse til det gamle franske aristokratiet. Correa mente bankene var direkte skyld i bankkrisen i 2000. På tross av at Correa innførte flere lover som banksektoren var kritisk til, samarbeidet han også med den, og bankene profiterte godt på den økonomiske veksten som fulgte ${ }^{66}$.

I likhet med Chávez, gikk Correa til frontalangrep på mediene, og beskyldte dem for å drive politisk kampanje. Straffen var å nekte selskapene som eier medier offentlige kontrakter, en

\footnotetext{
${ }^{66}$ Wolff, 2018, op.cit.
} 
rekke rettsaker mot mediene, kontroll med artikler som ble publisert og en svært restriktiv kommunikasjons lov fra $2013 .{ }^{67}$

Forholdet til de militæret var heller ikke spesielt varmt. Correa sitt hovedfokus var å sikre uavhengigheten til de militære styrkene av USA, blant annet ved å støtte det konstitusjonelle forbudet mot utenlandske baser. Men militæret ble også i den nye konstitusjonen mer avhengige av presidenten, som blant annet fikk mandat til å utpeke de øverste lederne. Correa fjernet også en rekke $\varnothing$ konomiske privilegier til den militære eliten (inkludert et eget pensjonssystem), selv om militæret også fikk ledelsen av nye statseide bedrifter. ${ }^{68}$ Resultatet var et ambivalent forhold, med ofte splittede militære eliter. Utfordringen for Correa var snarere at han verken hadde en sterk institusjonsbasert elite eller noe sterkt politisk parti i ryggen. Det fant han sin egen løsning på.

\section{Populistene og alternative eliter}

Chávez var fullt klar over betydningen av å bygge opp en alternativ elite, ikke minst fordi han var avhengig av produktiv sektor for å sikre suksess for sin Bolivarianske revolusjon. Allerede i 2002 tok han et diskursivt grep for å skille mellom de gode og de onde elitene, som under en av sine lange TV-sendte taler, der han omdefinerer middelklassen, som ellers ofte assosieres med elite, til å være «folket»:

Fritt land og frie menn, folkelige valg og skrekk for oligarkiet... Men jeg må benytte anledningen til å avklare at middelklassen ikke er oligarkiet, ikke sant? Mediekampanjen fors $\varnothing$ ker å forvirre middelklassen, men middelklassen er folket, middelklassen er patriotisk, middelklassen er nasjonalistisk, middelklassen er fundamental for landet, middelklassen er ikke oligarkiet. Ikke engang hele overklassen er oligarkiet. Oligarkiet er et historisk begrep for de som har styrt makten bak kulissene, som har manipulert presidenter, kongresser og har konsentrert den økonomiske makten i få hender, og fornekter den samme middelklassen; de har fornektet folket i lang tid. Så vi skal hilse velkommen den nye middelklassen. Venezuela skal bli et stort land og et land med en stor middelklasse. Alle som er her i dag, nesten alle, tilhører den

\footnotetext{
${ }^{67}$ Catherine Conaghan «Surveil and Sanction: The Return of the State and Societal Regulation in Ecuador», i European Review of Latin American and Caribbean Studies / Revista Europea de Estudios Latinoamericanos y del Caribe, nr. 98, 2015, 7-27.

${ }^{68}$ Avilés, 2009, op. cit.
} 
blomstrende venezuelanske middelklassen. (Hugo Chávez, Mérida. 27 de enero de 2002. Aló Presidente $N^{\circ}$ 94)

Videre forsøkte Chávez å bygge opp en alternativ produktiv sektor til den han mente var dominert av den gamle eliten. At oljeprisen steg til over 100 dollar fatet i 2007 ga det helt nye muligheter til å bruke fordeling av grunnrenten fra oljeutvinning for å sikre politisk kontroll ${ }^{69}$. I tillegg til å sikre folkets gunst ved hjelp av sosiale programmer, ble oljepengene brukt til å subsidiere dollar og kanalisere billige dollar til bedrifter som kunne utfordre det gamle oligarkiets dominans. Han favoriserte systematisk mindre bedrifter med nasjonal kapital, og styrket arbeidsgiverforeningen Fedeindustria på bekostning av Fedecamaras som samlet større og mer internasjonale bedrifter som hadde støttet kuppet i $2002^{70}$.

Slike grep var ikke strengt tatt nye. Forskjellen fra tidligere var at de ble en del av et personalistisk politisk prosjekt, og pakket inn i en populistisk diskurs som sidestilte storbedrifter med djevelen. Etter 2007 ble maktkonsentrasjonen i Chávez hender enda tydeligere. På tross av at Chávez tapte valget om en rekke grunnlovsendringer i 2007, gjennomførte han gradvis endringen som styrket hans makt. Etter det kom den første nasjonale utviklingsplanen som etablerer «sosialisme for det 21. århundre». Den ble fulgt opp med etablering av flere hundre såkalte Bedrifter for Sosial Produksjon og Sosialistiske Bedrifter, sterkt subsidiert av regjeringen ${ }^{71}$. Samtidig ble organisasjonslivet forsøkt kontrollert ved at regjeringen etablerte konkurrerende organisasjoner til de allerede eksisterende innenfor de fleste samfunnsområder (inkludert fagforeninger og næringslivsorganisajoner), og underminerte førstnevntes tilgang til både finansiering og innflytelseskanaler ${ }^{72}$.

Mens begrepet «boliburgeoisie» er flittig brukt i mediene for å beskrive den nye eliten som vokste frem i løpet av den såkalte Bolivarianske Revolusjonen, er det omdiskutert hvorvidt vi egentlig kan snakke om en ny «klasse» eller et nytt bourgeoisie. ${ }^{73}$ Men det som er helt tydelig

\footnotetext{
${ }^{69}$ Fernando Dachevsky og Juan Kornblihtt, «The Reproduction and Crisis of Capitalism in Venezuela under Chavismo", i Latin American Perspectives, vol. 44, nr. 1, 2017, 78-93.

${ }^{70}$ Nicolás Esteban Grimaldi, Las corporaciones empresariales venezolanas. Un analisis de la composición social de Fedecamaras y Fedeindustria. Argentina, Presentado por el XV Congreso Nacional y V Latinoamericano de Sociología Judídic, 2018.

${ }^{71}$ Chris Carlson, The Struggle to Industrialize Venezuela. Venezuelaanalysis, 2007.

72 David Smilde, «From Partly to Full Conflict Theory: A Neo-Weberian Portrait of the Battle for Venezuela», i Tulia G. Faletti og Emilio Parrado, Latin America Since the Left Turn. Philadelfia: University of Pennsylvania Press 2017. 138-164.

73 Steven Ellner, «Pink-Tide Governments: Pragmatic and Populist Responses to Challenges from the Right», i Latin American Perspectives, vol. 46, nr. 1, 2019, 4-22.
} 
er at en betydelig økonomisk sektor som ble sett som «chavist» vokste frem. Mange av bedriftene var import-eksport bedrifter etablert for å dra nytte av tilgangen på billige dollar, men den nye eliten var særlig knyttet til statseide selskaper og banker. ${ }^{74}$

Samtidig innså Chávez etter hvert behovet for et politisk parti. Før valget 2006 ble Det Enhetlige Venezuelanske Sosialistpartiet (PSUV) etablert. Med det søkte han å styrke båndene til det sivile samfunnet som MVR manglet, minske motstanden mot politiske partier på grasrota, og begrense den stadig mer utbredte korrupsjonen blant grasrotorganisasjoner. ${ }^{75}$ PSUV utviklet seg i årene som kom til det man kan kalle et «hegemonisk parti» med bred oppslutning og med evne til å løse de økende interne konflikten i Chavismen. Som alle andre partier utviklet det seg også en partielite, som besatte de fleste høye posisjoner. Flere av disse overlapper tydelig med den nye $\varnothing$ konomiske eliten, men PSUV ble en tydelig kanal for sosial mobilitet og partieliten ble en viktig pressgruppe med egeninteresser i videreføring av den bolivarianske revolusjonen.

I kontrast var Correas viktigste, og etter hvert eneste, instrument for å iverksette det han kalte for «borgerrevolusjonen» statsapparatet, og det var her han fors $\varnothing$ kte å bygge opp en alternativ, teknokratisk elite. Correas manikeiske diskurs var hele tiden krydret med innslag av teknisk kunnskap. Correa vektla tiden sin akademiske bakgrunn og overlegne innsikt på de fleste av livets felt, og hans populisme er av De la Torre kalt «tecnopopulisme» ${ }^{76}$. Det var ikke som soldat, men som den $\emptyset$ verste opplyste leder, en slags «professor messias» at han skulle lede folket ut av miseren.

Correa hadde et klart mål om å styrke statens byråkratiske kapasitet, både sentralt og å styrke tilstedeværelsen i områder der staten i liten grad var tilstede ${ }^{77}$. Sentralt bygget han opp flere planleggings- og styringsenheter, med Planleggingssekretariatet (SENPLADES) som en nøkkelinstitusjon ${ }^{78}$. De ansatte i disse nye organene kom ikke, som ofte tidligere, fra den nasjonale $\varnothing$ konomiske eliten, eller fra internasjonale organisasjoner, som Verdensbanken. De

\footnotetext{
${ }^{74}$ https://www.elmostrador.cl/noticias/pais/2014/02/21/la-elite-de-millonarios-venezolanos-que-surgio-delos-negocios-con-el-estado-chavista/

${ }^{75}$ Steven Ellner, Rethinking Venezuelan Politics: Class, Conflict and the Chávez Phenomenon. Boulder: Lynne Rienner 2008.

${ }^{76}$ Carlos De la Torre, «El tenopopulismo de Rafael Correa: ¿Es compatible el carisma con la tecnocracia?», i Latin American Research Review,vol. 48,nr, 1, 2013, 24-43.

77 Pablo Andrade og Esteban Nicholls, «La relación entre capacidad y autoridad en el Estado: La construcción de un Estado 'Excepcionalista' en Ecuador» i European Review of Latin American and Caribbean Studies, nr. 103, 2017, 1-24.

${ }^{78}$ Francisco Sánchez og John Polga-Hecimovich, «The Tools of Institutional Change under Post-Neoliberalism: Rafael Correa's Ecuador», i Journal of Latin American Studies, vol. 51, nr. 2, 2019, 379-408.
} 
var i hovedsak rekruttert fra universitetene, basert på utdanning og teknisk erfaring ${ }^{79}$. Av alle ansatte i SENPLADES i 2013 var 70\% under 40 år, og 2/3 hadde mastergrad eller høyere akademisk $\operatorname{grad}^{80}$.

Etter hvert ble en stor del av Correas ministre og statssekretærer rekruttert fra dette nye teknokratiet. Teknokratiet bidro sterkt implementeringen av en utviklingspolitikk som skapte en betydelig forbedring på de fleste sosiale indikatorer over en periode på 10 år, og bygget seg etter hvert opp til en ny teknokratisk elite. Teknokratiet var imidlertid fullstendig avhengig av Correa's prioriteringer og meninger. Et eksempel er hans helomdreining i miljøpolitikken, der han først hadde støttet et konstitusjonelt forbud mot genmodifisering (GMOs). Etter først å ha rekruttert teknokrater som støttet avgjørelsen, skiftet han ut de viktigste for å sikre teknisk grunnlag for sin støtte til GMOs, mens han beklaget på TV at han hadde han ikke hadde stått sterkt nok imot «disse barnslige miljøvernerne» ${ }^{81}$.

\section{Populistenes endelikt}

Til syvende og sist var en stor del av støtten til Correa knyttet til hans direkte lederskap, og i tillegg til høye inntekter til statskassen som både finansierte styrkningen av staten, og omfattende sosiale programmer. Den folkelige støtten hans var høy gjennom hele regjeringstiden, og selv etter fallet i råvarepriser i 2014 som begynte å tære på den ecuadorianske $\varnothing$ konomien, falt aldri andelen som ga en positiv evaluering av hans regime til under 50\%. Det var imidlertid stadig tydeligere at landet var delt, og at støtten var mye sterkere i kystområdene rundt Guayaquil enn i innlandet. Da Correa ønsket å oppheve den konstitusjonelle begrensningen på presidentembetet til to perioder, fikk han motbør blant en gruppe kongressmedlemmer. Han fikk igjennom oppnevningen men måtte inngå et kompromiss som gikk på at det ikke ville være gyldig før etter valget i 2017. Det betydde at han ikke kunne stille til det valget, men kunne komme tilbake ved valget i 2021, og at PAIS måtte velge en annen kandidat til valget i 2017. Det stod mellom Correas nærmeste støttespiller Jorge Glas, og Lenin Moreno, også han tidligere visepresident, men mest kjent for sitt arbeid for handikappedes rettigheter. Moreno vant på stemmene fra innlandet ${ }^{82}$. Etter valget i 2017 verken kunne eller ville han fortsette Correa sin strategi. Landet var da på god vei ut i en ny økonomisk

\footnotetext{
${ }^{79}$ De la Torre, 2013. Op. Cit.

${ }^{80}$ Pablo Andrade og Joaquin Zenteno Hopp, «Changing biiosafety frames and new political forces in Correa's government», i Benedicte Bull og Mariel Aguilar-Støen, Environmental politics in Latin America: Elite dynamics, the left tide and sustainable development. Abingdon and New York: Routledge 2015, 92-11.

${ }^{81}$ Andrade og Zenteno Hopp, 2015. Ibid.

82 Julia D'Amours, Ecuador Prepares to Vote on Term Limits, COA, 2018.
} 
krise, i stor grad på grunn av Correas akkumulerte budsjettunderskudd og høye lånopptak. Moreno lanserte ideen om å «av-Correifisere» Ecuador, ved å underlegge en rekke konstitusjonsendringer som Correa hadde gjennomført, en folkeavstemning. I en kontekst der flere av Correas nærmeste medarbeidere var funnet skyldig i omfattende korrupsjon (deriblant Jorge Glas) vant Moreno, og Correas teknopopulisme var nærmeste eliminert som politisk kraft. Chavísmen overlevde derimot både Hugo Chávez sin død i 2013 og oljeprisfallet i 2014. Den overlevde også valget av Chávez sin langt mindre karismatiske utvalgte etterfølger Nicolás Maduro i 2013, og hans gradvise underminering av både frie valg og demokratisk valgte institusjoner, som Nasjonalforsamlingen der opposisjonen vant valget i 2015. Maduro styrte også gjennom en økonomisk krise som savner historisk sidestykke utenfor krigssoner. Mellom 2013 og 2019 mistet Venezuela 63 prosent av sitt Brutto Nasjonalforsamling.

I den krisen var det tre grupper av eliter som stod frem som Chavismens redningsmenn: militæreliten, partieliten, og den nye økonomiske eliten. Militæret gikk fra å ha en betydelig posisjon i den Bolivarianske revolusjonen under Chávez, til å bli en dominerende kraft under Maduro. Det dreide seg blant annet om at Maduro selv hadde begrenset tillit hos de militære og måtte gi betydelige konsesjoner for å sikre videre støtte. Det gjorde han ved å utnevne 5000 nye generaler, gi høyt rangerte militære kontroll med halvparten av ministeriene (deriblant de strategiske toll og matvaredepartementene), og da krisen satt inn for fulgt, matvarefordelingsprogrammet CLAP. I 2017 tok også militære over kontroll med oljeselskapet og det viktigste landbruksproduksjonsselskapet, i tillegg til å ha en nøkkelrolle i ulovlig handel med blant annet narkotika og metaller. Militæreliten fikk med andre ord både kontroll over voldsressurser og store deler av landets $\varnothing$ konomiske ressurser.

Partieliten dominerer de sivile ministerpostene, men også den Grunnlovgivende forsamlingen, som ble nedsatt i 2017 for å tilsidesette den da opposisjonsdominerte Nasjonalforsamlingen. Der sitter også representanter fra den nye økonomiske eliten, som finner nye veier til rikdom, på tross av et sterkt sanksjonsregime ved blant annet å styrke båndene til Russland, Iran og Tyrkia. I løpet av 2019 ble de fleste $\varnothing$ konomiske reguleringene som hadde kjennetegnet den «Bolivarianske Revolusjonen» opphevet. Det gjaldt ikke minst priskontroll og valutakontroll. Det bidro til en dollarisering av økonomien, og slutt på varemangel for de som hadde inntekter i dollar, og en $\emptyset$ konomisk bonanza for de tre sterkt overlappende nye elitene ${ }^{83}$. Selv om ingen

\footnotetext{
${ }^{83}$ Dette fenomenet er for nytt til at det finnes gode studier av det, men det finnes gode journalistiske artikler. Se for eksempel: Anatoly Kurmanaev and Isayen Herrera (2020) Venezuelas Capital is Booming: Is this the end of the revolution? https://www.nytimes.com/2020/02/01/world/americas/Venezuela-economy-
} 
av disse elitene er enhetlige eller uten friksjoner har alle sterke egeninteresser $i$ at regimet fortsetter, uansett hvor korrupt, ineffektivt, og autoritært det måtte være.

\section{Konklusjon}

Mens rollen til inkongruente eliter var et viktig poeng i tidlige populismestudier, har forholdet mellom populistiske ledere og bevegelser og eliter fătt liten plass i nyere populismestudier. Det har flere årsaker. Populismen bygger selv på en anti-elitistisk retorikk, og mange populistiske bevegelser har vært både forhatt og motarbeidet av det vi kan kalle tradisjonelle eliter. Forklaringer på hvorfor noen land er mer motstandsdyktige mot populistiske ledere og deres anti-instit ${ }^{84}$ usjonelle retorikk, har gjerne fokusert på styrken i de eksisterende institusjonene, snarere enn forholdet til eliter.

Vårt hovedargument er at forholdet til elitene er av avgjørende betydning, særlig for hvordan populistiske regimer utvikler seg over tid. For det første er eksistensen av inkongruente eliter, eller eliter som har bygget opp en eller annen ressurs, men ikke i like stor grad fått politisk makt, en viktig årsak til fremveksten av populistiske bevegelser. For det andre er populistiske ledere og bevegelser avhengige enten av støtte fra gamle eliter eller å generere nye. En helt tydelig forskjell på Hugo Chávez og Rafael Correa var førstnevntes bevisste strategi og suksess med å bygge opp alternative eliter, etter hans ublide møte med de eksisterende elitene i landet. Han komplementerte stadige verbale og juridiske angrep på den sittende eliten med en bevisst styrkning av en alternativ elite, bygget på kontroll med voldsressurser, organisatoriske ressurser (partiet) og økonomiske ressurser. Correa på sin side fors $\varnothing k t e$ å bygge opp en teknoratisk elite som var viktig for implementeringen av hans politiske prosjekt, men den var i all hovedsak avhengig av Correa som leder. Over tid har Correas «borgrerevolusjon» smuldret opp, mens er Chavismen blitt en politisk bevegelse som har gjennomgått en metamorfose gjennom det stadig mer autoritære regimet til Nicolas Maduro, men som ikke på langt nær er død. Det man kan trekke ut av denne erfaringen er at sjansene er større for at bevegelsen svekkes om den populistiske lederen forsvinner om man ikke har bygget opp en alternativ elite. Samtidig er demokratiet i større grad er svekket i Venezuela der Chávez sin populisme var understøttet av nye eliter, enn det ble i Ecuador.

\footnotetext{
dollars.html?smid=nytcore-ios-share\&fbclid=IwAR3EpSmokK7rxQ7-UFJF-6VPLMSEAbInMBLsbVjkcz7u9wZqhdcpw28CEE

${ }^{84}$ Francisco José Alfaro, Archipiélagos bajo la tormenta: Coaliciones y negociación a la luz de la autocratización en Venezuela, European Review of Latin American and Caribbean Studies, 2020, forthcoming.
} 
Spørsmålet er i hvilken grad likhetene i utgangspunktet mellom Cavez og Correa dreide seg om populisme. Var de to simpelthen autoritære ledere som var kommet til makten gjennom demokratiske kanaler? Det er en del av bildet, men fenomenene Chávez og Correa dreide seg i stor grad også om deres manikeiske diskurs som stadig tok nye grep for å dele befolkningen inn i gode og onde og sentrere makten rundt en «Jesu soldat» (Chávez) eller «professor messias» (Correa). Denne populismen skaper en splid hos mange ulike eliter fordi den er uforutsigbar, endringsorientert, og viser en grunnleggende forakt for eksisterende institusjoner. Som Ochoa Espejo ${ }^{85}$ har vektlagt, er den også kjennetegnet ved mangel på innebygde begrensninger på sin egen makt. Slik sett vil den alltid være en trussel mot eksisterende eliter, og bare ved å enten forene seg med dem (og skape nye manikeiske forestillinger) eller å bygge opp nye, vil populismen kunne bli en vedvarende politisk kraft.

Å bringe innsikt fra elite studier inn i studiet av populismen vil kunne berike den på flere måter. Som implisert over vil det kunne bidra til en bedre forståelse av både hvor og hvorfor en populistisk diskurs vinner gehør og det er grobunn for fremveksten av populistiske bevegelser, og hvorfor noen slike bevegelser overlever mens andre svinner hen etter lederens bortgang. I tillegg kan et fokus på hvordan eliter endrer seg åpne for studier av konsentrasjon av økonomisk og politisk makt under populistiske ledere av alle avskygninger. Ikke minst kan det være et viktig korreks til argumenter om at noen former for populisme er mer progressive og «ekte» enn andre, som for eksempel Mouffes argument om at populismen kan være en progressiv kraft, om den representerer motstand mot en nyliberal dominans. ${ }^{86}$ En inngående studie av den nye eliten i Venezuela som er samlet ved en anti-nyliberal diskurs burde være insentiv nok til å stille store spørsmålstegn ved det argumentet.

\footnotetext{
${ }^{85}$ Paulina Ochoa Espejo, «Populism or Democracy? Reexamining the Role “the People” in Twenty-First Century Latin American Politics», i Tulia G. Faletti og Emilio Parrado, Latin America Since the Left Turn. Philadelfia: University of Pennsylvania Press 2017. 165-188.

${ }^{86}$ Mouffe, 2018, op. cit.
} 